\title{
Traços de Kurt Jooss e Rudolf Laban na Trajetória de Sayonara Pereira e seus Desdobramentos
}

\author{
Mônica Fagundes Dantas \\ Universidade Federal do Rio Grande do Sul - UFRGS, Porto Alegre/RS, Brasil \\ E-mail: monica.dantas@ufrgs.br \\ Daniel Silva Aires \\ Universidade Federal do Rio Grande do Sul - UFRGS, Porto Alegre/RS, Brasil \\ E-mail: daniel_airess@hotmail.com
}

\section{Resumo}

Na entrevista, a Professora Doutora Sayonara Pereira discorre sobre o legado de Rudolf Laban e Kurt Jooss no seu trabalho, desde sua experiência de quase 20 anos como bailarina e coreógrafa na Alemanha, até os desdobramentos de sua prática artística e acadêmica no Brasil nos últimos 15 anos.

\section{Palavras-chave}

Dança. Tanztheater. Carreira em Dança.

Sayonara Pereira.
In this interview, Professor Sayonara Pereira reflects on the legacy of Rudolf Laban and Kurt Jooss in her work. She talks about her life and career as dancer and choreographer in Germany during almost 20 years and how this influenced her artistic and academic practice in Brazil over the last 15 years.

Dance. Tanztheater. Dance Career.

Sayonara Pereira. 
Figura 1 - Sayonara Pereira - foto que fez parte da Exposição Mulheres Negras na Dança (2017).

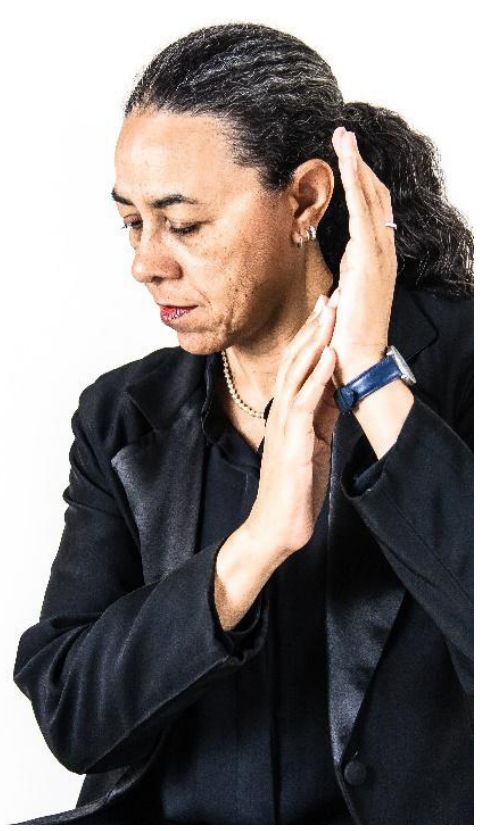

Fonte: Foto de Monica Cardim.

Nascida em Porto Alegre/RS, Sayonara Pereira (figura 1) iniciou seus estudos em dança em 1966, aos seis anos, na Escola de Dança João Luiz Rolla, onde concluiu o curso de ballet clássico e seguiu os estudos até 1980. Na sequência, foi contratada como professora do Conservatório Municipal da cidade de Montenegro/RS, (atual Fundação de Artes de Montenegro/FUNDARTE), no qual ministrava aulas no Departamento de Dança e onde permaneceu até 1985.

1 A Escola foi aberta em 1927 com dois departamentos que se propunham a trabalhar com todas as questões da educação artística. Um departamento dedicava-se aos estudos das Artes Plásticas e Visuais e o outro designava-se à arte da expressão e incluía Música, Dança e Língua. Dentro deste departamento encontramos ainda Teatro, Estilística e Crítica. Ficou definido que cada matéria possuía a sua total independência dentro da escola. Nesta escola estudaram grandes nomes da German Dance como Pina Bausch (1940-2009), Reinhild Hoffmann (1943) e Susanne Link (1944). Ver: PEREIRA, S. Novas aproximações com a Tanz Teatralidade. Ouvirouver, v. 11, n.1, p. 72-87, 2015. Disponível em: http://www.seer.ufu.br/index.php/ ouvirouver/article/view/32706. Acesso em: 20 jun. 2020.
Nesse meio tempo, em 1981, Sayonara foi a Nova Iorque/Estados Unidos, estudar no Alvin Ailey Dance Center. Ao deixar o Conservatório, que já havia se transformado em FUNDARTE, Sayonara Pereira iniciou uma jornada que percorreria por quase duas décadas. Em 1985, foi para a Alemanha estudar na renomada Folkwang Hochschule ${ }^{1}$ de Essen (escola dirigida na ocasião pela coreógrafa e bailarina alemã Pina Bausch). Sayonara morou na Alemanha até 2004 e a vivência no país teve papel essencial não só na sua formação como profissional, mas também como pessoa. Sayonara é Doutora em Artes-Dança pela Unicamp (2007), com um pós-doutorado na mesma universidade (2009). Desde 2010 é professora do Departamento de Artes Cênicas da Escola de Comunicação e Arte da Universidade de São Paulo (USP), onde dirige o LAPETT - Laboratório de Pesquisa e Estudos em Tanz Theatralidades. Em 2015-2016 fez pós-doutorado na Freie Universitat, em Berlim. Em junho de 2020 Mônica Dantas entrevistou Sayonara Pereira em sessão realizada por meio de plataforma digital, da qual participaram os integrantes do Grupo de pesquisa em práticas de formação, criação e documentação em dança e performance. O objetivo desta entrevista é compreender o legado de Rudolf Laban e Kurt Jooss no trabalho de Sayonara Pereira, desde sua experiência de quase 20 anos como bailarina e coreógrafa na Alemanha, até os desdobramentos de sua prática artístico-pedagógica. Além deste legado, nossa entrevistada aponta as parcerias marcantes em sua trajetória e o percurso de algumas de suas obras que se atualizam até hoje. Em colaboração com seus alunos e orientandos, nos indica ainda o desenvolvimento de uma pesquisa sobre o que tem chamado de Dramaturgia dos Afetos, finalizando nossa conversa nos explicando suas Lecture performances. 
É uma honra estarmos juntos nesse entrevista com a Professora Sayonara Pereira. Sejam bem-vindos. Iniciamos perguntando sobre a saída de Porto Alegre para a Alemanha em meados dos anos 1980.

Boa tarde a todos, todas e todes. Estou honrada por esse convite feito pelas minhas colegas da UFRGS. Antes de eu falar sobre a ida para para a Alemanha, tem a estada em Porto Alegre. No início dos anos 1980 eu tinha tido a oportunidade de participar de um grupo de dança chamado Grupo Terra, cuja história está muito bem retratada na dissertação de mestrado da Verônica Prokopp². O "Terra" vinha sendo um divisor de águas na cidade, dançávamos em parques, nas ruas, além dos palcos. Mas como sempre, este era um empreendimento independente, que não recebia apoio financeiro e o grupo não conseguiu se manter e terminou. Eu estava bastante triste nessa época, porque o grupo para o qual eu tinha dado os meus últimos quatro anos estava morrendo e eu tinha tomado aquele gostinho de ser profissional da dança. Eis que eu fico sabendo que uma companhia de dança chamada Folkwang Tanzstudio estava na cidade e que estavam todos hospedados no Hotel Embaixador. Então, da mesma forma que acontece nos filmes, em que aquela pessoa fica no hall de entrada do hotel esperando os bailarinos e a coreógrafa, eu estava lá, sentada naquele sofá, nervosa. De repente passa a Susanne Linke, aquela pessoa maravilhosa e incrível e eu falei: "Eu sou bailarina de Porto Alegre, eu quero dançar...". Ela foi educada, parou e perguntou: "Você tem ingressos para o espetáculo?". Eles estavam em cartaz no Theatro São Pedro, e eu, bailarina da cena livre de Porto Alegre, não tinha comprado ingressos para assistir o espetáculo. Então ela me falou: "Apareça

2 OLIVEIRA, Verônica Maria Prokopp de. A fotografia de Claudio Etges como elemento disparador da memória em dança: um mosaico histórico acerca da Terra Companhia de Dança do Rio Grande do Sul nos anos 1980 a 1984. 2019. Dissertação (Mestrado em Artes Cênicas). Universidade Federal do Rio Grande do Sul, Porto Alegre, 2019. Disponível em: http:// hdl.handle.net/10183/199283. Acesso em: 1 jun. 2020. na hora tal, no dia tal, você vai ter ingressos no seu nome. E depois, eu precisaria ver você dançar. Tem uma aula no dia tal, na hora tal. Apareça lá!". Eu pude então assistir o espetáculo do camarote central. $E$ isso aconteceu no nosso Theatro São Pedro, onde eu havia dançado pela primeira vez, como aluna da Escola do Seu Rolla ${ }^{3}$ em 1967. Eu assisti aquele espetáculo maravilhoso. A coreografia mais marcante era o Frauenballet, o Balé das Mulheres, que anos depois a Susanne Linke veio a remontar para o Grupo Corpo de Belo Horizonte. Eu fiquei entusiasmada, maravilhada com aquele tipo de dança. O que me chamava a atenção é que parecia que os bailarinos tinham composto a obra juntos, me parecia que tinha a colaboração daqueles corpos. Um dia depois eu fiz uma aula, a Susanne Linke veio assistir a aula como combinado, me viu e disse: "Você parece uma gazela longilínea, o que você quer com esse tipo de dança?" Então eu respondi: "Eu quero dançar!" Em 1984 eu tinha 24 anos. Ela me falou: "você tem que montar toda uma espécie de book e enviar para mim no endereço tal" (que era Belo Horizonte, ou seja, a companhia iria seguir em turnê pela América Latina e eles fechariam a turnê em Belo Horizonte). Quem me ajudou com as fotos foi o nosso amigo Claudio Etges, nós fizemos um book e eu enviei como combinado, com votos de boa sorte e de "tomara que ela leve mesmo". E a Suzanne Linke entregou meu material na Escola Folkwang. Um tempo depois eu recebi uma resposta da Linke, uma carta que eu guardo até hoje, dizendo: "entreguei teu material, temos que aguardar". Algum tempo depois recebi a resposta de que eu tinha sido aceita como aluna convidada. É importante eu deixar bem claro que, durante a minha formação na Escola Folkwang, eu

3 Escola de Dança de João Luiz Rolla, considerado o primeiro bailarino e primeiro homem a se tornar professor de ballet no Rio Grande do Sul. Ver: CUNHA, Maria Luisa da. Pelas fronteiras sem fim da dança: memórias da Escola de Dança João Luiz Rolla (19511986). 2016. Tese (Doutorado em Ciências do Movimento Humano). Universidade Federal do Rio Grande do Sul, Porto Alegre, 2016. Disponível em: http:// hdl.handle.net/10183/140963. Acesso em: 1 jun. 2020. 
fui uma aluna convidada, eu não fiz a formação institucional, como a gaúcha Magali Sander Fett nos anos 1990, nem como a gaúcha Carolina Paludo mais recentemente. Eu era uma bailarina convidada. E eu tive a oportunidade de ficar na Folkwang por muitos anos. Aos domingos, se tivesse aula, me ligavam: "Sayô, você não quer vir fazer aula? O professor precisa de tantos alunos". E lá estava eu. Eu sou uma pessoa querida do lugar, fui bem influenciada pelo trabalho desenvolvido na Escola, mas eu não sou formada por essa Universidade. Desse modo começa a minha história com a Alemanha. Em 1985 cheguei na escola para ser aluna convidada.

\section{Nesse tempo que você passou lá, você conseguia perceber alguma referência ao trabalho de Rudolf Laban e de Kurt Jooss? Isso era alguma coisa dita ou era algo que transparecia no trabalho corporal? E hoje, como você consegue avaliar essa relação?}

Naquela época, o que me chamou a atenção e o que me deixou um pouco incomodada é que o ballet era a técnica principal. O professor de ballet iniciava o aluno no primeiro ano, e o levava durante os quatro anos de graduação. Eu achei um pouco estranho, porque nos anos 1980 eu já estava muito mais interessada na dança moderna e suas variações. Eu não estava conseguindo entender a importância da dança clássica para o corpo de um bailarino de dança moderna, não estava muito claro para mim, hoje já está claro. Além do ballet clássico, quem ministrava as aulas de ballet moderno era a bailarina Malou Airaudo. Mas o divisor de águas eram as aulas do professor Hans Zullig que nasceu em 1914 e faleceu em 1992. Na obra Mesa Verde ${ }^{4}$, do Kurt Jooss,

4 Coreografia de Kurt Jooss com música de Fritz Cohen, estreiou em 1932, em Paris.Inspirado por uma dança da morte medieval e pelo rescaldo da I Guerra Mundial, esta obra retrata várias facetas da guerra: o debate, a mobilização, o combate, a especulação de guerra, os refugiados e, novamente, o debate; a morte está sempre presente. Considerada uma das obras coreográficas mais marcantes do século XX, A Mesa Verde é também o mais emblemático trabalho de Jooss. disponível em vídeo, Zullig incarna o Joker, aquele personagem que não morre, que é engraçado, que fica durante todo o tempo da peça driblando a morte. Esse era o nosso professor de dança moderna. Foi o estilo de dança moderna mais interessante que eu fiz na minha vida e que me impregnou bastante. Um fato interessante é que a Escola não era como a Universidade é para nós, ela era uma Hochschule, uma Escola Superior. Só mais recentemente que a Folkwang foi alçada à categoria de Universidade. Naquela época, era uma Escola Superior, voltada à prática. Por isso, não era costume fazer referência "aos princípios de Laban", ou "às ideias filosóficas de Jooss". Não tinha essa indicação nas aulas. Na aula da Malou Airaudo, por exemplo, ela trabalhava espacialidades. Na aula do Zullig, ele trabalhava toda a técnica de dança moderna, e a gente ainda identificava os resquícios do clássico. Na aula dele, fazíamos os exercícios na barra, que continham todos os elementos da dança clássica. Com o fondue por exemplo, que eu adorava, eu consegui entender um dos princípios da dança: a estabilidade do corpo ainda ereto e toda a dobradura da parte superior. Esse é um dos elementos mais importantes da dança, que eu continuo a utilizar. Tanto a compreensão de que o corpo tem que estar no eixo, como o entendimento de que plié tem que estar aprofundado, e que a parte superior do corpo tem de estar mais arredondada. Essa última é a noção de volume do tronco, que é muito enfatizada nas aulas. Um outro mestre que era também um "carimbo" da Escola era Jean Cébron (1927 - 2019). Ele faleceu ano passado e foi um bailarino que, após a Segunda Guerra, veio para o Chile, então a dança nas universidade do Chile, ou mesmo as companhias de dança, são muito influenciadas pela presença de Cébron na América do Sul. A aula dele era muito complicada e muito longa, durava mais de duas horas, com sequências pré-estabelecidas, um pouco parecidas com a aula de Mar- 
tha $\operatorname{Graham}^{5}$ (não a técnica, mas as sequências já pré-existentes) e "quem chegou, chegou meu filho!" e "quem não chegou fica chorando", porque tu tens que conseguir acompanhar a aula, tem que seguir mimeticamente. Ele ficava sentado, olhando, e as sequências se repetiam. Eu não tive tanta empatia com essa técnica, ensinada dessa maneira. Eu me identificava muito com as aulas do Zullig. E ambos trabalharam com Jooss. O professor Jean Cébron também fez parte da companhia de Kurt Jooss. Depois vem a geração mais jovem, que vocês conhecem aqui em Porto Alegre, como o Lutz Förster. Ele foi bailarino da companhia da Pina Bausch durante muitos anos; ele estudou nos Estados Unidos, na escola de José Limón, então quando ele foi para a Folkwang, levou essa influência de José Limón para suas aulas. E havia também o ensino do Folclore Espanhol, que hoje a gente já diria manifestações populares, aqui no Brasil. É interessante que, naquela época, todos os bailarinos da companhia que estavam no caminho de virarem pedagogos, como Dominique Mercy, Ed Kortlandt eram gente como a gente, assim, „a vida como ela é“. Então, eu não me lembro de nenhuma aula na qual se dissesse: "Vamos ter agora trabalhar as oito ações do movimento". Não, estava tudo inserido nas aulas, mas não era enfatizado. Toda a ideia e a aura do Jooss estavam muito próximas, porque ele tinha sido professor da Pina Bausch e da Susanne Linke, com quem a gente fazia aula como colegas. A Susanne Linke viveu muitos anos, ela está ainda viva e inclusive hoje é o aniversário dela. Ela fazia aula diariamente com a gente, e era uma coisa muito gostosa porque ela tinha todas as dificuldades que todas as pessoas normais têm. Uma coisa muito linda que acontecia. Então, ela fazia muitas aulas junto com a gente, porque existia essa companhia que eu tinha conhecido

5 Martha Graham (1894-1991), bailarina, coreógrafa e professora estadounidense, considerada um dos pilares da dança moderna, desenvolveu uma técnica de dança baseada na intensificação do ato de respirar e no tronco como centro do movimento. A técnica é composta por sequências pedagógicas bem estruturadas. no Brasil em 1984, Folkwang Tanzstudio, que foi dirigida pela Linke. Havia uma aula de manhã, às 10h30, que era a aula da companhia, que eu fazia como convidada. A Susanne Linke também fazia essa aula. Então, a energia do Jooss parecia mais presente do que a do Laban. Essa era minha sensação.

Parabéns para a Susanne Linke! Gostarí-
amos de saber como toda essa experiên-
cia influenciou no seu trabalho como baila-
rina, como coreógrafa e como professora.

Eu tive toda aquela experiência de estar num país novo, e logo eu fui acolhida por um grupo independente, dirigido pela coreógrafa Christine Brunel. Ela tinha acabado de criar o Thanztheater Christine Brunel, do qual eu participei durante oito anos, de 1985 até 1992 . Isso foi muito importante na minha vida, porque ela era oriunda da Escola Folkwang, uma bailarina importante, formada no repertório da Susanne Linke. Ela tinha toda aquela técnica, aquela tecnologia, eu diria, de Jooss no seu corpo. Ela já estava replicando isso com acentos próprios, e eu tive a oportunidade de trabalhar muitos anos com a Brunel. Entrei como bailarina, me transformei em bailarina-solista, em assistente de coreografia, em assistente técnica dos trabalhos dela e, quando eu já não estava mais atuando como bailarina da companhia, fui convidada a dar aulas para os novos bailarinos que iam chegando. Brunel influenciou muito a minha forma de trabalhar, de pensar a dança, por muito tempo. Ela esteve em Porto Alegre em 1988 e juntas ministramos um curso, para várias turmas, na Academia Mudança. Fizemos também uma apresentação no Theatro São Pedro, em uma programação em que ela dançava três solos e eu dançava um; eram quatro solos no total. Foi muito importante ter trabalhado com a Brunel.

Houve outras experiências para as quais eu não estava preparada. Hoje eu vejo isso. No anos 1980, com meus 20 e poucos anos, saída de Porto Alegre com as informações que eu tinha, eu comecei logo a trabalhar com dois artistas independentes. 
Um deles Peter Kowald, um músico incrível que, se vocês assistirem o filme que a Pina Bausch fez em 1989, O Lamento da Imperatriz, terão a oportunidade de vê-lo; ele é o músico que aparece tocando um contrabaixo gigantesco dentro do trenzinho que passa na cidade de Wuppertal, aquele trem em suspenso. Com ele, eu trabalhava com improvisação, algo que eu não estava acostumada. Naquela época eu era uma bailarina que gostava muito mais das estruturas prontas, e dentro dessas estruturas, eu me movia, eu tentava encontrar o meu modo de dançar. Então coisas assim, muito especiais, eram para mim naquele momento um pouco estranhas. $A$ segunda artista independente com quem eu trabaIhei e que também mudou bastante a minha concepção de vida, foi Barbara Heinisch. Ela era uma artista visual que tinha sido aluna do Joseph Beuys, e trabalhava com um tipo de estrutura, uma tela que ela pintava ao vivo, e por trás da tela havia um bailarino pressionando essa tela e a pegada do pincel. Notem, isso era anos 1980 na Alemanha, hoje tudo isso é normal, mas para mim isso tudo era também novo. Eu tenho um vídeo em que ela rasga a tela e me puxa lá de dentro e eu estou nua. O povo era muito louco, e eu meio tensa. Eu desejava fazer minha aula de dança, "limpa", organizada, meu fondue na aula do professor Zullig, e a vida me chamando para essas coisas. Por isso que eu digo que hoje, em 2020, aos 60 anos de idade: "olha tudo que eu fiz lá no final dos 20 , início dos meus 30 anos", mas na época eu ficava um pouco assustada. Então essas pessoas influenciaram muito meu modo de pensar, de ver a dança. Eles já estavam transdisciplinares, a transdisciplinariedade já era normal para essas pessoas naquela época, para mim não tanto.

\section{Para além dessas experiências com colaboração, você poderia nos falar um pouco sobre seus tra- balhos solos?}

Eu comecei a trabalhar com brasileiros na Alemanha, o que foi muito incrível: cena livre de dança, um monte de pessoas da minha geração, espalhadas pela Europa. Eu acho interessante falar para quem vai ler o texto que, para a minha geração, quando a gente decidia dançar, a gente tinha muito poucas opções no Brasil. Mesmo que hoje a gente ainda tenha poucas opções, hoje existem os Cursos de graduação em dança nas universidades, do Oiapoque ao Chuí. No meu tempo, o curso de graduação em dança que existia era na Bahia e eu nem sabia muito sobre isso. Eu pensava em ir embora, se fosse possível e foi o que me aconteceu. Eu e muitas pessoas pensavam assim, tanto que eu encontrei esses brasileiros na Alemanha,. Um deles foi o Armando Pekeno, com quem fiz um primeiro trabalho chamado A Noite dos Sábios, ou Simplesmente uma Procura. Dançamos em Porto Alegre, e em outras capitais, foi muito legal. Em 1990, eu estava com esse meu colega Armando Pekeno e Simone Rorato, bailarina gaúcha também, com quem trabalhei por muitos anos. Primeiro começaram essas parcerias, primeiro vieram os duetos com a Simone, uns três duetos e então comecei a fazer meus solos. Eu tinha tido um problema muito sério na coluna, eu estava desenganada, tinham dito que eu não podia mais dançar. Aos poucos a Brunel me chamou pra dar aula e sobrava muito tempo para mim, lá no estúdio vazio. Ela tinha um pequeno teatro, e eu ficava lá trabalhando. Quando fiz meu primeiro solo em 1996, Saudades (figura 2), parecia que ele estava pronto dentro de mim. Depois na sequência, em 1997, criei Pulsações e depois Caminhos (figura 3). Agora estou trabalhando de novo nessa coreografia. Vieram uma série de solos e as críticas sempre diziam: era uma mistura de essenense brasileira, e eu comecei a perceber que, em todos os solos que eu fazia, surgiam muitas coisas do Brasil, embora isso ainda não estivesse muito claro para mim. Eu tinha ido pra Alemanha, tinha ido conhecer aquele tipo de dança e quando eu ia pra cena, para tentar organizar aqueles sentimentos e o que eu queria que as pessoas percebessem, surgia aquela brasilidade; a trilha sonora era um exemplo. E havia outras referências latentes nesse trabalho. E esse trabaIho prosseguiu por todo o tempo em que eu vivi na 
Alemanha, eu sempre fazia coreografias e solos, algo muito presente no meu modo de coreografar.

Figura 2 - Saudades (1996). Coreografia e interpretação: Sayonara Pereira.

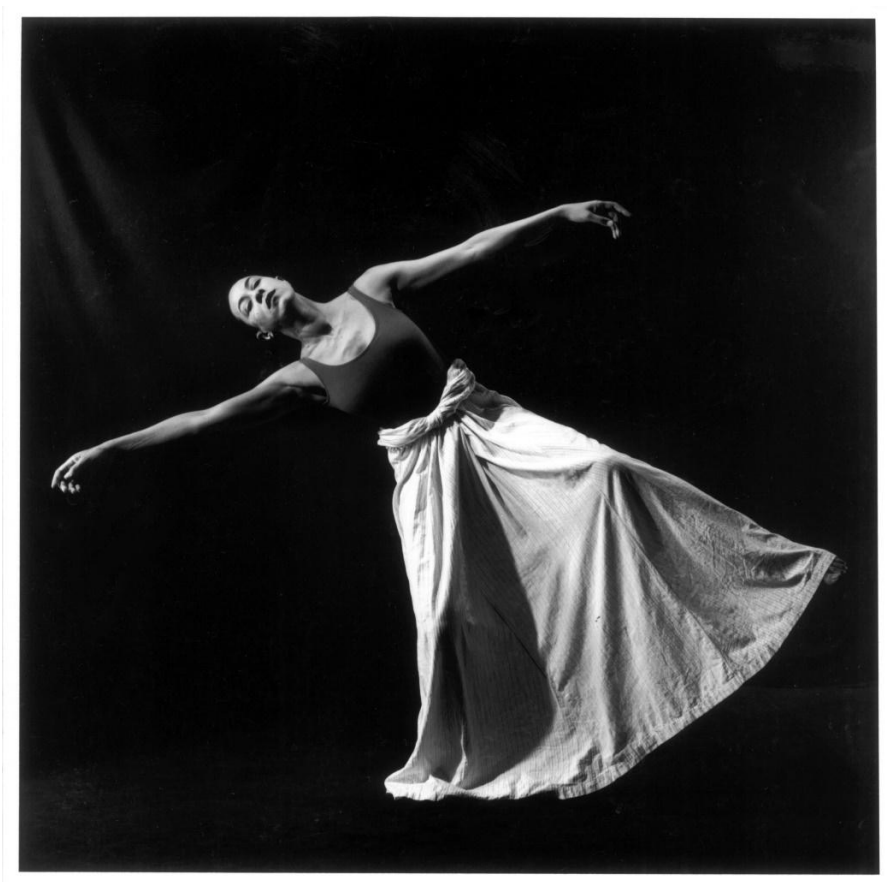

Fonte: Foto de Mathias Hoffmann.

\section{Gostaríamos agora de tratar da experiência como} professora, mas antes queríamos que você nos falasse da formação em licenciatura em dança na Alemanha.

Eu já estava começando a cansar da cena livre e já me aproximava dos quarenta anos com aquela dificuldade financeira latente. Não reclamava muito, porque sempre tive alguma subvenção, embora naquele bolo grande da verba do estado, metade era para o teatro oficial, um quarto para os artistas famosos, e um quarto para todo o resto do povo. Eu pertencia provavelmente "a todo resto do povo". Então, quando já estava ficando difícil aquilo tudo, eu recebi uma visita, aquelas coisas da história: eu estava em casa num verão e um amigo meu, Antrifo Sanches, professor da UFBA, foi me visitar. O Antrifo tinha estudado na Escola Folkwang, tinha sido bailarino do Balé Teatro Castro Alves e quando ele voltou para o Brasil, ele conseguiu conciliar as duas coisas: ser professor e bailarino profissional. Ele me falou: "Sayô, porque você não faz Pedagogia da Dança em Colônia?". Eu respondi: "Colônia?". Porque eu tinha aquele olhar Folkwang, eu sempre morei em Essen, na cidade onde a Folkwang fica localizada. Mas resolvi tentar. Tu escrevias uma carta para dizer porque queria fazer o teste. Bom, e me chamaram para esse teste na Hochschule Für Musik-Tanz / Köln, que hoje é conhecida como a Universidade de Música e Dança. O teste consistia numa entrevista e eu precisava dar uma aula, e a aula era de ballet. E eu passei, nós éramos um grupo muito bacana de seis pessoas. Na Alemanha, para fazer Licenciatura de Dança, que eles chamam Pedagogia da Dança, o bailarino deveria comprovar formação em dança e pelo menos seis anos de atividade profissional. Só então ele poderia se inscrever para fazer Licenciatura em Dança. Bem diferente do que a gente conhece no Brasil, porque as pessoas optam por fazer licenciatura com talvez menos conhecimento da dança. Então, nós éramos seis pessoas: um alemão, uma alemã, um vietnamita, uma taiwanesa, um cara da América Central e essa que vos fala, brasileira. Eu me dava muito bem com os asiáticos. E foi um tempo difícil na minha vida, porque eu seguia morando no meu apartamento em Essen e eu percorria todos os dias $100 \mathrm{~km}$ de trem para Colônia, onde era a Universidade. Era muito desgastante. Nos meus últimos anos na Alemanha eu me esgarcei ao máximo, foi muito pesado aquele curso e eles não eram muito afetuosos, e eu sou toda afeto, até estou tentando desenvolver esse conceito de Dramaturgia dos Afetos. Porque eu vivo de afetos, eu amo a dança. Só me ensinaram amor pela dança e assim que eu me manifesto no mundo. E essa escola era bastante rígida, mas foi lá que eu aprendi a organizar o meu fazer. As coisas que mais ou menos eu achava que sabia, eu consegui organizá-las lá, o que foi bem positivo. Eu, que tinha trabalhado esses 19 anos na Alemanha, quando eu estava mais ou menos no meu $16^{\circ}$ ano, eu tinha trabalhado basicamente com dança moderna alemã ou German Dance, e voltei a trabalhar com técnica de Graham. 
Porque nessa universidade, a técnica de dança moderna era Graham, ensinada por corpos de pessoas que tinham trabalhado realmente na companhia. Eu tive aula de técnica com a professora, Armgard von Bardeleben. Ela trabalhou realmente com Graham e ela tinha muita afetividade na sua docência, mas a técnica é difícil; na época eu já tinha 41 anos, voltando a sentar no chão, girar, quarta posição, era bem complexo para aquele corpo daquele momento. $\mathrm{E}$ a gente também tinha metodologia de técnica de Graham com a Heide Tegeder. E era incrível, porque a Heide Tegeder tinha sido bailarina de Pina Bausch e ela dava metodologia de Graham, então era meio estranho. Mas o meu maior presente naquela escola eram as aulas de Psicologia e as aulas com a querida Claudia Jeschske. Foi nessa escola que eu "bati de frente", no sentido de que fui realmente apresentada a Laban. Porque tivemos quatro semestres de Kinetografia, ou seja, escrita da dança. Quatro semestres que eu confesso a vocês que eu penei, porque Labanotation é para os fortes. Porque é matemática pura e parece música ao mesmo tempo, porque tem uma grafia muito específica. Essa universidade então trouxe esses tópicos para mim: retomar Graham e entrar em contato com Labanotation.

\section{E quando e porque você decidiu retornar ao Brasil?}

Eu já estou aqui há um bom tempo, acho que já faz uns 14 anos, mas sempre me perguntavam isso. $\mathrm{E}$ eu acho que não tem volta. No meu caso não tem volta, porque eu acho que a vida move a gente, a gente está sempre indo. Então eu pensei, por que não Brasil? Eu me perguntava: se tem universidade do Oiapoque ao Chuí, eu me vejo passando essa afetividade para as pessoas, num lugar onde elas queiram a minha presença, e não de mochilinha nas costas dando aula de dança, workshop. Eu nunca fui assim, apesar de ser uma mulher negra, eu não dava aula de samba, eu dava aula de Modern Tanztheater na Alemanha. German Dance na Alemanha não era uma coisa comercial. E eu dizia: "meu Deus eu quero dar aula disso, é por aí que eu me comunico". Eu pensei que eu precisava organizar esses saberes. Nos últimos anos, eu vinha fazendo tudo: eu fiz a proficiência em alemão, tinha o certificado, fui agraciada com uma bolsa do $\mathrm{DAAD}^{6}$. Assim, eu vim para o Brasil com alguma segurança. Me naturalizei alemã, e pensei: "vou ter o passaporte pra eu poder me mover, se tudo no Brasil der errado, eu posso vir pra Alemanha e aí vou ver do que eu vou viver". E a Claudia Jeschske, que foi uma pessoa maravilhosa para mim, me incentivava: "você tem que ir pro Brasil, você tem que disseminar a dança teatral". Então pensei em estudar na UNICAMP, pois eu entendi que eu deveria buscar um caminho acadêmico, a academia era o que me trazia para o Brasil, essa oportunidade de ter dança na universidade do Oiapoque ao Chuí. Na Alemanha há três ou quatro universidades com cursos de dança, e a minha chance de conseguir uma vaga era minúscula. Na UNICAMP fui recebida com todo carinho pela Professora Doutora Livre Docente Inaicyra Falcão dos Santos, que me aceitou do jeito que eu era. Ela é uma especialista em Manifestações Populares Brasileiras e processos de criação ${ }^{7}$ e eu queria falar em dança teatral, a minha proposta de projeto de mestrado seria perceber a influência da dança teatral

6 DAAD - Deutscher Akademischer Austauschdienst/ Serviço Alemão de Intercâmbio Acadêmico - é a maior organização alemã no campo de intercâmbio acadêmico, oferecendo uma larga escala de bolsas de estudos para alemães e estrangeiros para estudo, pesquisa e ensino dentro e fora da Alemanha.

7 Ver: FALCÃO, Inaicyra. Corpo e Ancestralidade Uma proposta Pluricultural de: dança- arte- educação. Salvador: Edufba, 2002. 
no trabalho da Carlota Albuquerque ${ }^{8}$, uma gaúcha contemporânea nossa, e do Henrique Rodovalho ${ }^{9}$, que dirige a Quasar. Eu fiz o Mestrado muito rapidamente, porque estava centrada, tinha bolsa e pude me instalar em Campinas; fui para a qualificação em 9 meses, a banca indicou que eu fosse direto para o doutorado e que buscasse os elementos da German Dance na minha dança. Eu me emocionei, era tudo que eu queria. Quando acabou minha bolsa da Alemanha, do DAAD, ganhei a da FAPESP (Fundação de Amparo à Pesquisa do Estado de São Paulo) e, na UNICAMP, fui contratada com bolsa de estágio docente, eu dava mais aula que todo mundo porque eu queria dar aulas. Eu fui mostrando meu interesse de trabalhar na academia, porque realmente eu tinha dado muita aula na minha vida desde os 15 anos, mas eu nunca tinha dado aula na academia, onde tu vais desenvolver um determinado tema durante todo o semestre (e na semana passada eu estreei dando aula virtual). A gente está sempre estreando nessa vida, nunca dá pra sentar e achar que acabou. Mas talvez a minha história seja essa, hoje é linda, com luzes, mas a minha história foi difícil do início ao fim. Da UNICAMP o que que virou? Virou o concurso da USP, no qual eu deveria ser "a zebra", por que era um departamento de artes cênicas. Mas eu fiz o

8 Coreógrafa e diretora do Terpsí Teatro de Dança fundado em 1987, que já apresentou obras emblemáticas como Quem É? (1989), Ditos e Malditos: desejos da clausura (2009) em diferentes festivais nacionais e internacionais. Pelos seus trabalhos coreográficos e trajetória foi agraciada com diferentes prêmios entre eles em 2010 A Ordem do Mérito Cultural (OMC), que é uma ordem honorífica dada a personalidades brasileiras e estrangeiras como forma de reconhecer suas contribuições à cultura do Brasil. É também Graduada em dança, e em 2006 iniciou o Centro de Estudos Coreográficos Terpsí, um espaço para a pesquisa, experimentação, diálogo e reflexão sobre Dança.

9 Henrique Rodovalho dirige a Quasar Cia de Dança desde 1988, e tornou-se uma das referências na Dança Contemporânea brasileira e internacional. Recebeu diferentes premios nacionais e internacionais que recebeu diretamente ou indiretamente por suas obras para Quasar Cia. de Dança. Sua caligrafia pessoal é inconfundível,e seu repertório de obras diversificadas apresenta elementos de brasilidade, humor, irreverência e muita qualidade técnica vista através dos corpos afinados dos seus bailarinos. concurso e o ponto que caiu foi? Laban! Eu não sei, só sei dizer que eu fiquei muito alegre com aquele ponto. A prova era teórico-prática, eu precisava dar uma aula, preparar toda a aula em torno do tema. Como era na área das artes cênicas, dentre os 20 pontos da prova, havia desde "O Teatro de Stanislavski”, "O Teatro Chinês”, e o ponto número 1, que era Laban! Laban me colocou na USP! Eu posso dizer isso também. Eu preparei uma aula com os movimentos, com as ações, foi bom. O legado de Laban inclusive me deu um emprego, vamos dizer assim. Então, essa coisa de voltar, acho que não se volta, acho que se continua a andar, vislumbrando a próxima parada. E por que não o Brasil? Minha língua, minha pátria, enfim. Era meio esperado.

\section{Como os estudos de doutorado e pós-doutorado no Brasil se reencontraram com teu trabalho desenvolvido na Alemanha?}

Eu costumo dizer que eu me sentia e que me sinto como uma pessoa que protege o Tanztheater, porque inclusive em português se traduz para Dança-Teatro. Eu não protejo isso, a Dança-Teatro. Eu protejo o Tanztheater ou a Dança Teatral, que é uma experiência tão inscrita na minha carne. E o que eu pesquiso hoje é justamente isso: memórias inscritas no corpo, transmissibilidade, e essa ideia das Dramaturgias dos Afetos, que eu estou desenvolvendo. Comecei a trabalhar com a transmissibilidade porque eu sempre me interrogava: "porque as peças que a gente faz, quando passa um tempo, ficam num vídeo e ninguém mais entra em contato com isso?" Então eu comecei a conversar com uma aluna minha com quem eu tenho uma relação muito especial, a Luiza Banov. Eu a conheço desde 2004, quando eu cheguei na UNICAMP, e ela tinha 19 anos. Ela era a materialidade do tempo que eu não tinha passado no Brasil. A tradução é essa. Ela tinha 19 anos, era o tempo que eu não tinha vivido aqui. Então, com a Luiza, foi toda essa tessitura de uma relação acadêmica e afetiva; ela é minha herdeira. Não tem como não dizer isso. Em 2009 ela se 
interessou também pela Dança Teatral, foi convidada pela Susanne Linke para ir para a Folkwang, no momento em que a Susanne Linke estava remontando o Balé das Mulheres/ Frauenballett. Hoje eu sou madrinha das filhas dela e ela aceitou aprender Caminhos (figura 4), e as questões sobre a originalidade da obra, sobre quem é o original e quem é a tradução em uma obra coreográfica estão presentes na cena e fazem parte da minha pesquisa atual.

Figura 3 - Caminhos (2019). Coreografia: Sayonara Pereira Interpretação: Sayonara Pereira e Luiza Banov.

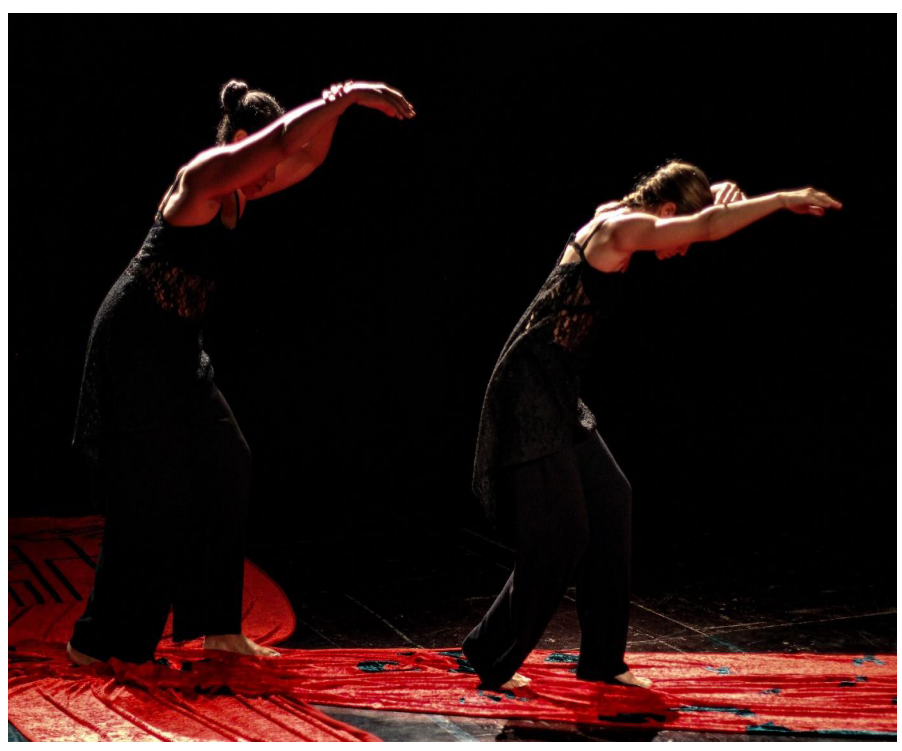

Fonte: Foto de Gabriel Góes.

A estreia do trabalho foi em Porto Alegre e tivemos muita sorte de virmos para um grande evento ${ }^{10}$, para dançar no Theatro São Pedro, o primeiro teatro onde eu tinha dançado na minha vida. Hoje, quando eu vejo o vídeo eu penso: "Gente, eu comecei a dançar aqui! Em 1967". Era 2017, eram "quinhentos" anos depois. Então esse trabalho está se desconstruindo, mas ele tem uma coisa muito sedimentada. Ontem a gente apresentou pela primeira vez no formato lecture vídeo performance. Aos poucos, eu comecei a aparecer cada vez mais na cena, como o autor que persegue a obra. Eu fico perseguindo-a,

$102^{\circ}$ Gestos Contemporâneos, em Porto Alegre. porque a Luiza é, hoje, a obra. Só de falar para vocês, eu já estou emocionada. Imagina ver a guria de 35 anos e a mulher de 60 atrás, é bem interessante. A gente está trabalhando essa estrutura lecture performance como forma de apresentar a obra. Já escrevemos um texto e publicamos como capítulo de livro ${ }^{11}$. Em resumo: o solo Caminhos (parte 1) foi transmitido (parte 2). A parte 3 é lecture performance e das doze cenas, selecionamos seis. Ficou com a seguinte estrutura: Sayô dança; Luiza dança três danças, interrompemos e convidamos o público para fazer o jogo do telefone sem fio, só que com gestos da peça. Daí o público vem, experimenta os gestos da peça, pedimos para as pessoas se sentarem, contamos o processo de criação. Sem ninguém esperar, voltamos a dançar. E agora tem essa nova versão, lecture vídeo performance, que a gente nunca imaginou que iria fazer, mas, com a pandemia, tornou-se necessário. Para nós, o trabalho já era virtual, pois há um momento, no final da peça, em que a gente começa a mostrar alguns slides, alternando nossas imagens: Luiza, eu, Luiza, eu. O público fica se questionando quem é quem: mesmo lugar, mesma foto, só que com pessoas diferentes. A gente já estava no virtual, então decidimos transformar isso em vídeo. Mas a gente está experimentando, porque ninguém sabe quanto tempo quem está como público, em casa, aguenta ficar vendo um vídeo. Então é rápido, são três minutos. E essa virou a quarta versão: lecture vídeo performance. De 1998 ela já chegou em 2020. O que significa que a gente está sempre em movimento. Então não tem volta, só tem ida.

$112^{\circ}$ BANOV, Luiza; PEREIRA, Sayonara. LECTURE-PERFORMANCE: Encontrando novos rastros a partir da transmissão da peça CAMINHOS (1998). In: COSTA, Daniel Santos. Corpo e diásporas performativas. São Paulo: Paco Editorial, 2019. p. 309-322. 
Retornando ao termo Tanztheater, eu gostaria que você nos apontasse opções de tradução para Tanztheater e que nos dissesse quais são os legados, as heranças, as memórias que esse termo traz.

Eu estou procurando ainda. No meu livro de 2010, Rastros do Tanztheater ${ }^{12}$, eu me dei a permissão de seguir esses rastros, porque eu estive próxima das pessoas do Tanztheater. Às vezes as pessoas escrevem sobre meu curriculum vitae: "dançou com a Pina Bausch". Não! Então, eu me permiti seguir os rastros do Tanztheater, e me permito ainda, por ter tido essa proximidade, por ter trabalhado com a Cristine Brunel, que trabalhou com a Susanne Linke, que trabalhou com a Pina Bausch, que trabalhou com o Kurt Jooss, que trabalhou com Dore Hoyer, que trabalhou com Rudolf Laban. Então, eu fui até lá, estive perto. Eu pertenci. Nos anos 1980, eu estava nesse movimento. Quando eu fui fazer minha tese, eu pensava: "traduzir é trair". Hoje eu até já não penso tanto que traduzir é trair, mas eu pensei e eu penso, e eu falo na tese: se uma palavra correta existisse pra traduzir Tanz que é "dança" e Theater que é "teatro", só que em alemão é uma coisa só, é uma expressão só, então eu diria dança teatral, e não Dança-Teatro, pois, para mim, Dança-Teatro separa. Veja bem, dança teatral todo mundo faz, mas Tanztheater eu acho que quem faz é Pina Bausch. E se tu observares, Mônica Dantas, eu troquei o nome do meu grupo. O nome do meu grupo é Laboratório de Pesquisa e Estudos em Tanz Theatralidades porque quem sou eu para fazer Tanztheater? Tanztheater é de Pina Bausch e seus herdeiros consanguíneos diretos. Eu sou Sayô Pereira de Porto Alegre, que tive a chance de ir até lá conhecer tudo isso. Ser amiga de alguns, ter sido aluna de outros, mas até aí é tudo o que eu

12 PEREIRA, Sayonara. Rastros do Tanztheater no Processo Criativo de ES-BOÇO - Espetáculo cênico com alunos do Instituto de Artes da UNICAMP. São Paulo: Annablume, 2010. OU Rastros do Tanztheater no Processo Criativo de ES-BOÇO - Espetáculo cênico com alunos do Instituto de Artes da UNICAMP - Tese de Doutorado - Instituto de Artes, Universidade Estadual de Campinas, 2007. tenho direito. "E por que não tem aula de Tanztheater? As pessoas dão aula de Dança-Teatro". Bom, as pessoas dão aula de Dança-Teatro, de algo que elas criaram, entende? Isso é algo que me cansa um pouco, porque você não traduz Commedia dell'arte? Tu falas: "a pessoa está fazendo comédia da arte"? Não. Porque fica até ruim em português. Commedia dell'arte é Commedia dell'arte. Então, deixa Tanztheater para Pina Bausch e seus discípulos e a gente trabalha com dança teatral, com teatralidades na dança, porque aí eu acho que todo mundo faz. E não é porque eu falo em cena que eu estou fazendo Tanztheater. Não. É complexo. Não sei. Isso é o que eu acho e eu já acho isso há bastante tempo. $\mathrm{E}$ quando eu estive lá na Alemanha de novo, quando eu via pessoas da minha geração, elas não falavam em Thanztheater, elas diziam "Não, não! Eu estou na contemporaneidade!". Porque ninguém queria se meter nesse lugar. Porque tem um pertencimento. Quem é da família, quem não é família. Enfim, essas coisas que a gente sabe pelas nossas próprias famílias. Então é isso. Eu me utilizo da expressão assim.

\section{Gostaríamos que você falasses mais sobre como a sua prática como professora e pes- quisadora foi se transformando no Brasil.}

Eu trabalhei com essas pessoas todas que eu comentei, e também com Seu Rolla, Erenita Parmegiani Teixeira, Regina Guimarães, Cecy Frank, Ricardo Ordoñes, muitos professores de ballet. E então a gente faz aquele "shake, shake, shake" e escolhe coisas que a gente prefere que estejam na nossa aula. Na verdade, eu tive sorte de cair no Departamento de Artes Cênicas, porque eu sou obrigada a traduzir essa espécie de saber do meu ofício para aqueles corpos, porque eu não queria dar uma aula que deixasse as pessoas infelizes. É uma língua que a pessoa precisa de uma vida inteira para aprender e é sempre sofrimento. Eu até conto para os meus alunos: "Gente, eu passei a metade da minha vida preferindo ir tomar banho depois da aula pra ver se melhorava, porque a aula tinha sido horrível". Então, 
eu não quero que as pessoas saiam infelizes da minha aula. Porque ninguém quer mais ficar parado. As pessoas já têm essa tensão. Está tudo fragmentado. As pessoas fazem aula em casa, olhando no celular, então eu tive que me atualizar. Não sei, eu ainda estou longe da atualização, não pensem vocês, ainda exijo fila. Eu tenho aquele meu toc de fila. Eu preciso de fila para eu enxergar, porque é muita gente e corpos querendo dizer diferentes gramáticas. Então eu modifiquei certas abordagens que se fizeram necessárias para que eu chegasse numa abordagem cada vez com mais imagens e sensações. O campus da USP é uma dádiva. Dá para levar as pessoas para a rua, para fazerem coisas que nunca fazem. Temos dois teatros gigantescos, em um deles cabem 200 pessoas sentadas, 250 ou 300 . E cada palco é de uns $200 \mathrm{~m}^{2}$, sem nenhuma coluna, tem espaço para 30 pessoas fazerem aula, tranquilo! Quiçá 40! Mesmo assim eu vou para a rua, para eles sentirem certas coisas, o vento no rosto. A gente trabalha com essa coisa de perder a base, mas ter equilíbrio em cima, se não fica muito teórico. Então vai mesmo! Sobe nas pedras e sei lá. No fim eu estou fazendo a mesma coisa, com todo respeito, que a Mary Wigman fez, que o Laban fez, que quando começou o século $X X$ as pessoas estavam nesses lugares, não é mesmo? Vendo a natureza no seu corpo. Porque é isso: tem que entender isso para tentar se entender, quando for para a cena. Incentivo que as pessoas saibam línguas, porque isso volta pra Jooss, que é a coisa que mais me marcou, em tudo que eu li a respeito dele, que cada pessoa já está pronta e a gente, como professor e coreógrafo tem que ter aquele olhar afiado para lapidar aquelas qualidades, que essa pessoa já está trazendo. Como orientar e guiar para que ela encontre algo mais confortável. Eu penso que técnica liberta porque, quanto mais técnica eu souber, eu vou estar livre depois para me expressar, ao invés de eu ficar "me dançando". Essa está entre as minhas expressões mais famosas: Não se dance! Pelo amor de Deus! Não queira se dançar. Siga instruções! Então depois, livre, você vai, corre lá fora, seja feliz. Claro que eu estou escrevendo sobre isso, pois para falar sobre este tema, não é tão divertido assim. É mais estruturado do que isso.

\section{Gostaríamos de saber se você é afeita à do-} cumentação, onde é que você guarda todas essas histórias, para além do teu corpo?

Eu sou bem organizada e tive chance de ter trabalhado com a Brunel, que valorizava muito as fotos; tenho muitas fotos. Eu tenho menos vídeos, até porque, naquele tempo a gente não fazia muito vídeo. Atualmente, é só pegar o celular e filmar. Mas antes não. Mas eu tenho caixas de cada obra, com as fotos organizadas. Nesse momento, como estou me organizando para o concurso de livre docência, estou tentando digitalizar essa documentação. Outro dia eu fiquei escaneando não sei quantos documentos dos anos 2000, e são vinte anos. Mas guardei quase tudo, de antes também. Eu sempre fui de coleção, de álbum de criança... Então eu tenho bastante coisa organizada.

Figura 4 - Caminhos (2019). Coreografia e interpretação: Sayonara Pereira.

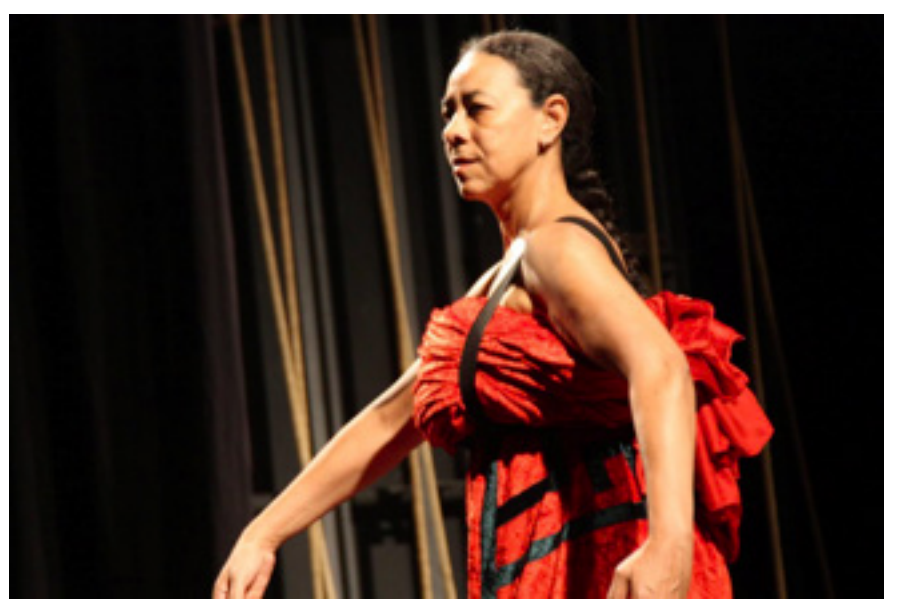

Fonte: Foto de Vera Athayde. 


\section{Referências}

BANOV, Luiza; PEREIRA, Sayonara. LECTURE-PERFORMANCE: Encontrando novos rastros a partir da transmissão da peça CAMINHOS (1998). In: COSTA, Daniel Santos. Corpo e diásporas performativas. São Paulo: Paco Editorial, 2019. p. 309-322.

CUNHA, Maria Luisa da. Pelas fronteiras sem fim da dança: memórias da Escola de Dança João Luiz Rolla (1951-1986). 2016. Tese (Doutorado em Ciências do Movimento Humano). Universidade Federal do Rio Grande do Sul, Porto Alegre, 2016. Disponível em: http://hdl.handle.net/10183/140963. Acesso em: 1 jun. 2020.

FALCÃO, Inaicyra. Corpo e Ancestralidade Uma proposta Pluricultural de: dança- arte- educação. Salvador: Edufba, 2002.

OLIVEIRA, Verônica Maria Prokopp de. A fotografia de Claudio Etges como elemento disparador da memória em dança: um mosaico histórico acerca da Terra Companhia de Dança do Rio Grande do Sul nos anos 1980 a 1984. 2019. Dissertação (Mestrado em Artes Cênicas). Universidade Federal do Rio Grande do Sul, Porto Alegre, 2019. Disponível em: http://hdl. handle.net/10183/199283. Acesso em: 1 jun. 2020.

PEREIRA, Sayonara. Rastros do Tanztheater no Processo Criativo de ES-BOÇO - Espetáculo cênico com alunos do Instituto de Artes da UNICAMP - Tese de Doutorado - Instituto de Artes, Universidade Estadual de Campinas, 2007.

Rastros do Tanztheater no Processo Criativo de ES-BOÇO - Espetáculo cênico com alunos do Instituto de Artes da UNICAMP. São Paulo: Annablume, 2010.
Novas aproximações com a Tanz Teatralidade. Ouvirouver, v. 11, n.1, p. 72-87, 2015. Disponível em: http://www.seer.ufu.br/index.php/ouvirouver/article/view/32706. Acesso em: 20 jun. 2020.

Recebido: 05/07/2020

Aceito: $11 / 09 / 2020$

Aprovado para publicação: 27/11/2020

Este é um artigo de acesso aberto distribuído sob os termos de uma Licença Crea- tive Commons Atribuição 4.0 Internacional. Disponível em: <http://creative commons.org/licenses/by/4.0>.

This is an open-access article distributed under the terms of the Creative Commons Attribution License 4.0 International. Available at: <http://creative commons.org/licenses/by/4.0>.

Ce texte en libre accès est placé sous licence Creative Commons Attribution 4.0 International. Disponible sur: <http://creativecommons.org/licenses/by/4.0>. 